\title{
Heat stress assessment according to the wet-bulb globe temperature (WBGT) index among workers of a steel mill in 2014
}

\author{
Ghanbary Sartang A, MSc ${ }^{1}$, Palyzban F, BSc ${ }^{2 *}$, Abedi M, MSc ${ }^{3}$, Shovkati M, BSc ${ }^{4}$, Sadeghi, $^{2}$ \\ $\mathrm{S}, \mathrm{MSc}^{5}$
}

1- MSc in Occupational Health Engineering, School of Health, Isfahan University of Medical Sciences, Isfahan, Iran. 2- BSc in Occupational Health Engineering, Health Network and Treatment Eyvan City, Ilam, Iran. 3- MSc Student in Health Safety and Environment, Center Tehran Azad University of Medical Sciences, Tehran, Iran. 4- BSc in Occupational Health Engineering, Shahid Beheshti University of Medical Sciences, Tehran, Iran. 5- MSc in Industrial Engineering, Dept. of Industrial Engineering, Islamic Azad University Ilam, Ilam, Iran

Received: August 2017, Accepted: October 2017

Background: Heat stress in the steel industry is considered as a serious threat to the health and safety of workers. A wide spectrum of complications and diseases from mild disorders such as burning sensation to fatal conditions such as thermal shock may occur due to uncontrolled thermal stress. In this study, heat stress assessment was performed according to the wet-bulb globe temperature (WBGT) index among workers of a steel mill in 2014.

Materials and Methods: In this cross-sectional study, 11 stations of a steel mill were selected in which occupational exposure to heat stress was possible. The WBGT index was used to measure heat stress. The collected data were analyzed using descriptive statistics in SPSS software.

Results: The results showed that the highest exposure to heat stress was in the rolled operator unit $\left(31.5^{\circ} \mathrm{C}\right)$ and the least exposure to heat stress was in the main operator room $\left(18.52{ }^{\circ} \mathrm{C}\right)$. Personnel working in the poker furnace operator, lift operator, ruffing operator, wrench operator, rolling work operator, scissors operator, and lathe operator units were exposed to higher heat stress than the threshold limit value for heat exposure recommended by the American Conference of Governmental Industrial Hygienists (ACGIH).

Conclusions: The findings of this study showed that steel mill workers are exposed to heat stress and the heat conservation planning intervention action should be conducted to reduce exposure.

Keywords: Heat Stress, Occupational Exposure, Workers, Steel

\section{Introduction}

Heat stress is an important aspect in the lives of individuals working under high-temperature conditions for long hours. Heat stress particularly at outdoor workplaces in hot-dry climates can disrupt the physical or mental functions and negatively effect human performance (1) Heat stress, as a physical agent, is a common hazard at high-temperature outdoor and indoor workplaces. The assessment of occupational exposure to heat stress is performed using some internationally recognized indices.

The wet-bulb globe temperature (WBGT) index approved by the International Standard Organization is one of the most well-known and most frequently used indices for estimating heat stress among workers in hot environments. This index considers the effects of the basic parameters in any human thermal

\footnotetext{
* Corresponding author: Feizolah Palyzban, Health Network and Treatment Eyvan City, Ilam, Iran. E-mail: f.palizban@ymail.com
} 
environment (2). Exposure to heat stress can lead to physical and psychological health problems. The effects of heat on human health range from a mild annoyance, such as heat rash, to death due to heat stroke (3). Working in a hot-dry environment can lead to severe performance degradation, and consequently, to a sharp drop in labor productivity. Heat stress is accumulation of heat in the body and disrupts thermal equilibrium and imposes some changes on the human body, which cannot be compensated for; therefore, heat exposure can negatively influence the cognitive and psychomotor abilities of the workers (4). Based on the WBGT, the working capacity of people begins to decline at higher than $25^{\circ} \mathrm{C}$, and it will be difficult to do any work at higher than $40^{\circ} \mathrm{C}$. Moreover, due to climate change and global warming, workplace heat stress and productivity is becoming an increasing challenge for lowincome and middle-income countries (5). Heat stress is well recognized among hazardous physical agents that might be present in work environments. The 3 main factors that influence heat stress are clothing, work demands, and environmental conditions. The evaluation of heat stress is based, first, on exposure limits that consider the environmental conditions and metabolic rate (6). Operations at sites like chemical plants, steel mills, smelters, and steam tunnels involving high air temperatures, radiant heat sources, high humidity, direct physical contact with hot objects, or strenuous physical activities have a high potential for inducing heat stress in employees engaged in such operations. There is a continuous and dynamic interaction between people and their surroundings that produces physiological and psychological strain. This can lead to discomfort, annoyance, subtle and direct effects on performance and productivity, and effects on the health and safety of workers (7). Increase in core temperature body is the most common physiological response to heat stress; when there is not enough heat exchange with the environment via convection and evaporation, the deep body temperature exceeds the allowable limit of $38{ }^{\circ} \mathrm{C}$, and so, heat is accumulated in the body. As a result, awareness of the impacts of environmental conditions on people is important in terms of the improvement of employee performance and productivity and prevention of work accidents (8). Heat stress is caused by many factors such as individual factors, environmental factors, and management factors. Individual risk factors can decrease heat tolerance, and play an important role in the incidence of heat stress disorders. Therefore, the present study aimed to perform heat stress assessment according to the WBGT index among workers of a steel mill in 2014.

\section{Material and Methods}

In this cross-sectional study, 11 stations of a steel mill were selected in which occupational exposure to heat stress was possible. The work stations studied included the poker furnace operator, lift operator, ruffing operator, wrench operator, rolling work operator, scissors operator, lathe operator, hydraulic jack operator, packing operator, and discharge operator units, and the main operator room. To measure the heat stress, WBGT (TES-1369 B model, Taiwan) was used with a precision of \pm $0.5{ }^{\circ} \mathrm{C}$. The WBGT index is one of the indicators of heat stress which provides the temperature variables of wet temperature, dry temperature, and radiant temperature of the composition. According to ISO 7243 standard, WBGT index was measured at a height of 1.1 meter above the ground for each station's worker. Finally, according to the type of work for each person (light, medium, or heavy), the measurements obtained were compared with the standard heat stress provided by the American Conference of Governmental Industrial Hygienists (ACGIH). Based on this categorization, all of the workstations mentioned above were considered as light load tasks. Measurements were made at the hottest hours of the day from 13:00 to 15:00 PM. All the participants in the study had undergone 
heat acclimatization. The measured WBGT index was compared to the threshold limit values recommended by the ACGIH, which is also accepted by the Occupational exposure limit Iran (9). After collecting the measurement results, statistical analyses were performed using descriptive statistics in SPSS software (version 20, IBM Corporation, Armonk, NY, USA).

Table 1: Demographic characteristics of the participants

\begin{tabular}{ccc}
\hline Variable & Mean \pm SD & Maximum-Minimum \\
\hline Height $(\mathrm{cm})$ & $184.70 \pm 2.07$ & $187-171$ \\
\hline Weight $(\mathrm{kg})$ & $81.23 \pm 7.20$ & $89-68$ \\
\hline Age & $36.20 \pm 3.41$ & $44-27$ \\
\hline Work experience & $8.41 \pm 1.34$ & $10-2$ \\
\hline
\end{tabular}

\section{Results}

In this cross-sectional study, 11 men participated. Table 1 shows the mean and standard deviation of the demographic characteristics of the participants (height, weight, age, and work experience).

The work stations with WBGT of less than threshold limit values are presented in table 2 .
According to table 2, the amount of heat stress in all of the units was of less than the threshold limit value. The moisture content of the main operator room $(35.1 \%)$ was higher than the other units. According to table 2, the highest rate of heat stress was in the discharge operator unit $\left(27.4{ }^{\circ} \mathrm{C}\right)$ and the lowest rate of heat stress was in the main operator room $\left(18.51{ }^{\circ} \mathrm{C}\right)$.

Table 2: Mean WBGT index at work stations with WBGT of less than threshold limit value

\begin{tabular}{ccccccc}
\hline $\begin{array}{c}\text { Place of } \\
\text { measurement }\end{array}$ & $\begin{array}{c}\text { WBGT } \\
\text { standard }\left({ }^{\circ} \mathrm{C}\right)\end{array}$ & $\begin{array}{c}\text { Exposure time } \\
(\text { minute })\end{array}$ & $\begin{array}{c}\text { Work-rest } \\
\text { program }\end{array}$ & $\begin{array}{c}\text { Amount of } \\
\text { humidity }(\%)\end{array}$ & $\begin{array}{c}\text { WBGT } \\
\text { measured }\left({ }^{\circ} \mathrm{C}\right)\end{array}$ & $\begin{array}{c}\text { Exposure } \\
\text { assessment }\end{array}$ \\
\hline $\begin{array}{c}\text { Hydraulic jack } \\
\text { operator unit }\end{array}$ & 29.5 & 480 & $\begin{array}{c}100 \% \\
\text { work }\end{array}$ & 9 & 26.63 & $\begin{array}{c}\text { Less than } \\
\text { standard limit }\end{array}$ \\
\hline $\begin{array}{c}\text { Discharge } \\
\text { operator unit }\end{array}$ & 29.5 & 60 & $\begin{array}{c}100 \% \\
\text { work }\end{array}$ & 10.2 & 27.40 & $\begin{array}{c}\text { Less than } \\
\text { standard limit }\end{array}$ \\
\hline $\begin{array}{c}\text { Main operator } \\
\text { room }\end{array}$ & 29.5 & 60 & $\begin{array}{c}100 \% \\
\text { work }\end{array}$ & 35.1 & 18.51 & $\begin{array}{c}\text { Less than } \\
\text { standard limit }\end{array}$ \\
\hline $\begin{array}{c}\text { Packing } \\
\text { operator unit }\end{array}$ & 29.5 & 60 & $\begin{array}{c}100 \% \\
\text { work }\end{array}$ & 8.6 & 26.70 & $\begin{array}{c}\text { Less than } \\
\text { standard limit }\end{array}$ \\
\hline
\end{tabular}

WBGT: Wet-bulb globe temperature

The work stations with WBGT of higher than the threshold limit values are presented in table 3. According to table 3 , in all of the units, the amount of heat stress was higher than the threshold limit value. The moisture content of the rolling work operator unit $(14.2 \%)$ was higher than the other units.
According to table 3, the highest rate of heat stress was observed in the rolling work operator unit with $31.5^{\circ} \mathrm{C}$ and the lowest rate of heat stress was observed in the units (poker furnace operator, scissors operator, and lathe operator units) with $29.6{ }^{\circ} \mathrm{C}$. 
Table 3: Mean WBGT index at work stations with WBGT of higher than the threshold limit value

\begin{tabular}{|c|c|c|c|c|c|c|}
\hline $\begin{array}{c}\text { Place of } \\
\text { measurement }\end{array}$ & $\begin{array}{c}\text { WBGT } \\
\text { standard }\left({ }^{\circ} \mathrm{C}\right)\end{array}$ & $\begin{array}{l}\text { Exposure time } \\
\text { (minute) }\end{array}$ & $\begin{array}{l}\text { Work-rest } \\
\text { program }\end{array}$ & $\begin{array}{c}\text { Amount of } \\
\text { humidity }(\%)\end{array}$ & $\begin{array}{c}\text { WBGT } \\
\text { measured }\left({ }^{\circ} \mathrm{C}\right)\end{array}$ & $\begin{array}{c}\text { Exposure } \\
\text { assessment }\end{array}$ \\
\hline $\begin{array}{c}\text { Poker } \\
\text { furnace } \\
\text { operator unit }\end{array}$ & 29.5 & 480 & $\begin{array}{l}100 \% \\
\text { work }\end{array}$ & 10.6 & 29.6 & $\begin{array}{l}\text { Higher than } \\
\text { standard level }\end{array}$ \\
\hline $\begin{array}{l}\text { Lift operator } \\
\text { unit }\end{array}$ & 29.5 & 60 & $\begin{array}{l}100 \% \\
\text { work }\end{array}$ & 8.7 & 29.7 & $\begin{array}{l}\text { Higher than } \\
\text { standard level }\end{array}$ \\
\hline $\begin{array}{c}\text { Ruffing } \\
\text { operator unit }\end{array}$ & 29.5 & 60 & $\begin{array}{l}100 \% \\
\text { work }\end{array}$ & 9.9 & 30.5 & $\begin{array}{l}\text { Higher than } \\
\text { standard level }\end{array}$ \\
\hline $\begin{array}{c}\text { Wrench } \\
\text { operator unit }\end{array}$ & 29.5 & 60 & $\begin{array}{l}100 \% \\
\text { work }\end{array}$ & 8.8 & 30.1 & $\begin{array}{c}\text { Higher than } \\
\text { standard level }\end{array}$ \\
\hline $\begin{array}{l}\text { rolling work } \\
\text { operator unit }\end{array}$ & 29.5 & 60 & $\begin{array}{l}100 \% \\
\text { work }\end{array}$ & 14.2 & 31.5 & $\begin{array}{c}\text { Higher than } \\
\text { standard level }\end{array}$ \\
\hline $\begin{array}{c}\text { Scissors } \\
\text { operator unit }\end{array}$ & 29.5 & 60 & $\begin{array}{l}100 \% \\
\text { work } \\
\end{array}$ & 9.1 & 29.6 & $\begin{array}{c}\text { Higher than } \\
\text { standard level }\end{array}$ \\
\hline $\begin{array}{c}\text { Lathe } \\
\text { operator unit }\end{array}$ & 29.5 & 60 & $\begin{array}{l}100 \% \\
\text { work }\end{array}$ & 15 & 29.6 & $\begin{array}{l}\text { Higher than } \\
\text { standard level }\end{array}$ \\
\hline
\end{tabular}

WBGT: Wet-bulb globe temperature

\section{Discussion}

Heat stress is a harmful physical agent in many industries. It can cause fatigue, lethargy, decreased productivity, increased errors, increased number of accidents, and also heatrelated diseases. Therefore, there is a wide range of problems in this regard and they require special attention. As a result, the measurement, evaluation, and control of heat stress are an important step forward in providing occupational health and safety. In developing countries like Iran, more researches on this issue are necessary (10). The present paper also indicated that there was a significant difference between the different work stations in WBGT index, and when compared to ISO 7243 standard, it was indicated that the two groups were different in terms of exposure to heat stress. The present findings seem to be consistent with other studies. Heat stress and strain among workers of aluminum smelters was studied by Logan et al. They reported a heat stress rate of higher than the allowed levels, which is in agreement with the present study (11). The results of this study showed that workers employed in the steel industry are exposed to heat stress and interventions to reduce exposure to heat stress are necessary. Minard et al. evaluated thermal stress in the steel industry and concluded that workers in the steel industry were exposed to heat stress that confirmed the findings of the present study (12). Individuals in the poker furnace operator, lift operator, ruffing operator, wrench operator, rolling work operator, scissors operator, and lathe operator units were exposed to more than the permitted heat stress level. Monazam et al. examined the relationship between heat stress and thermal hazard in a steel mill. The results of their study showed that workers employed in the steel industry are exposed to heat stress and heat protection methods should be carried out for workers (13). This finding confirmed the findings of the present study. Azimi et al. investigated heat stress in the Steel plant and concluded that the melting platform did not have suitable atmospheric conditions and measures must be taken to control the radiation heat (14). Hemmatjo et al. examined heat stress in the petrochemical industry with ISO 7243 standard and concluded that exposure to heat stress was higher than the threshold limit value and management and engineering control was necessary to reduce heat stress (15). Hajizadeh et al. evaluated thermal stress in a brick workshop and concluded that the WBGT index in these workshops is higher than the permitted limit and interventions should be used to reduce the 
thermal stress in this industry (16). Motamedzade et al. concluded that through appropriate designing and control methods use, such as insulation shield and increased airflow velocity, optimal thermal comfort based on national heat exposure limits could be reached (17). Venugopal et al. concluded that reducing workplace heat stress will benefit industries and workers via improving workers' health and productivity (18). It is recommended that similar studies be carried out to further assess the steel industry in terms of heat stress.

\section{Conclusion}

The findings of this study showed that steel mill workers are exposed to heat stress in the poker furnace operator, lift operator, ruffing operator, wrench operator, rolling work operator, scissors operator, and lathe operator units. Thus, heat conservation planning and interventions should be conducted to reduce exposure to heat stress. Measures such as reducing the exposure time, using cooling vests and mechanical ventilation systems, providing workers with cool water, designing a radiation absorber around the heat sources, creating sufficient space between heat source and person, and enclosing individuals must be taken.

\section{Acknowledgments}

This article is based on a project at Eyvan Health Center and is supported by Eyvan Health Center and the authors of this article are obliged to acknowledge all the individuals who have been involved in this project.

Conflict of interest: None declared.

\section{References}

1. Jafari MJ, Teimori G, Khodakarim S, AssilianMahabadi $H$. Investigation the relationship between heat strain score index and physiological parameters among open pit miners. Journal of Safety Promotion and Injury Prevention 2015; 3(4):213-22.
2. Krishnamurthy M, Ramalingam P, Perumal K, Kamalakannan LP, Chinnadurai J, Shanmugam $\mathrm{R}$, et al. Occupational heat stress impacts on health and productivity in a steel industry in southern India. Saf Health Work 2017; 8(1):99104.

3. Golbabaei F, Monazzam MR, Hematjo R, Hosseini M, Fahang-Dehghan S. The assessment of heat stress and heat strain in pardis petrochemical complex, Tehran, Iran. International Journal of Occupational Hygiene 2013; 5(1):6-11.

4. Hancock PA, Vasmatzidis I. Effects of heat stress on cognitive performance: the current state of knowledge. Int J Hyperthermia 2003; 19(3):355-72.

5. Dash SK, Kjellstrom T. Workplace heat stress in the context of rising temperature in India. Curr Sci 2011;101(4):496-503.

6. Abdel-Ghany AM, Al-Helal IM, Shady MR. Human thermal comfort and heat stress in an outdoor urban arid environment: a case study. Advances in Meteorology 2013; 2013:Article ID 693541, 7 pages.

7. Parsons KC. Environmental ergonomics: a review of principles methods and models. Appl Ergon 2000; 31(6):581-94.

8. Chen ML, Chen CJ, Yeh WY, Huang JW, Mao IF. Heat stress evaluation and worker fatigue in a steel plant. AIHA J (Fairfax, Va) 2003; 64(3):352-9.

9. Golmohammadi R, Aliabadi M. Air Conditioning control in Workplace. Shiraz: Shiraz University of Medical Sciences; 2012. P.124-70.

10. Kjellstrom T, Holmer I, Lemke B. Workplace heat stress, health and productivity-an increasing challenge for low and middleincome countries during climate change. Glob Health Action 2009; 2:10.

11. Logan PW, Bernard TE. Heat stress and strain in an aluminum smelter. Am Ind Hyg Assoc J 1999; 60(5):659-65.

12. Minard D, Goldsmith R, Farrier PH Jr, Lambiotte BJ Jr. Physiological evaluation of industrial heat stress. Am Ind Hyg Assoc J 1971; 32(1):17-28.

13. Monazzam MR, Jafariroodbandi A, Mohammadi P, Amirzadeh F, Tabatabaee SHR. A study on heat stress and its risk assessment in a steel factory. Iran Occupational Health 2013; 9(4):41-9.

14. Haji Azimi E, Khavanin A, Aghajani M, Soleymanian A. Heat stress measurement according to WBGT index in smelters. Journal of Military Medicine 2011; 13(2):59-64.

15. Hemmatjo $R$, Zare $S$, Heydarabadi $A B$, Hajivandi A. Investigation of heat stress in 
workplace for different work groups according to ISO 7243 standard in mehr petrochemical complex, Assaluyeh, Iran. Journal of Paramedical Sciences 2013; 4(2):97-101.

16. Hajizadeh R, Golbabaei F, Monazzam MR, Farhang-Dehghan S, Ezadi-Navan E. Productivity loss from occupational exposure to heat stress: a case study in brick workshops/Qom-Iran. International Journal of Occupational Hygiene 201; 6(3):143-8.
17. Motamedzade M, Eshaghi M, Sepehr $\mathrm{P}$. Evaluation of the workers exposure to heat and presenting intervention to control heat stress in profile factory. Journal of Occupational Hygiene Engineering 2014; 1(3):53-9.

18. Venugopal V, Chinnadurai JS, Lucas RA, Kjellstrom T. Occupational heat stress profiles in selected workplaces in India. Int J Environ Res Public Health 2015; 13(1):pii:E89. 